\title{
Care Recommendations for the Respiratory Complications of Esophageal Atresia-Tracheoesophageal Fistula: The International Network of Esophageal Atresia, Respiratory Complications Working Group
}

\author{
Anastassios Koumbourlis ${ }^{1}$, Yvonne Belessis ${ }^{2}$, Mary Cataletto $^{3}$, Renato Cutrera ${ }^{4}$, Emily \\ DeBoer $^{5}$, Mikhail Kazachkov ${ }^{6}$, Sophie Laberge ${ }^{7}$, Jonathan Popler ${ }^{8}$, Federica Porcaro ${ }^{9}$, and \\ Tom Kovesi ${ }^{10}$ \\ ${ }^{1}$ Children's National Medical Center \\ ${ }^{2}$ Sydney Children's Hospital Randwick \\ ${ }^{3}$ New York University Medical Center \\ ${ }^{4}$ Bambino Gesù Childrens' Hospital, IRCCS \\ ${ }^{5}$ University of Colorado Anschutz Medical Campus \\ ${ }^{6} \mathrm{NYU}$ Langone Medical Center \\ ${ }^{7} \mathrm{CHU}$ Sainte-Justine \\ ${ }^{8}$ Children's Physician Group Pulmonology \\ ${ }^{9}$ Bambino Gesù Children's Hospital \\ ${ }^{10} \mathrm{CHEO}$, Ottawa
}

June 5, 2020

\begin{abstract}
Tracheoesophageal fistula (TEF) with esophageal atresia (EA) is a common congenital anomaly that is associated with significant respiratory morbidity throughout life. The objective of this document is to provide a framework for the diagnosis and management of the respiratory complications that are associated with the condition. As there are no randomized controlled studies on the subject, a group of experts used a modification of the Rand Appropriateness Method to describe the various aspects of the condition in terms of their relative importance, and to rate the available diagnostic methods and therapeutic interventions on the basis of their appropriateness and necessity. Specific recommendations were formulated and reported as Level A, B, C based on whether they were based on "strong", "moderate" or "weak" agreement. The tracheomalacia that exists in the site of the fistula was considered the main abnormality that predisposes to all other respiratory complications due to airway collapse and impaired clearance of secretions. Aspiration due to impaired airway protection reflexes is the main underlying contributing mechanism. Flexible bronchoscopy is the main diagnostic modality, aided by imaging modalities, especially CT scans of the chest. Non-invasive positive airway pressure support, surgical techniques such as tracheopexy and rarely tracheostomy are required for the management of severe tracheomalacia. Regular long-term follow-up by a multidisciplinary team was considered imperative. Specific templates outlining the elements of the clinical respiratory evaluation according to the patients' age were also developed.
\end{abstract}

\section{INTRODUCTION}

Congenital tracheoesophageal fistula (TEF) is almost always (92\% of cases) associated with esophageal atresia (EA) (commonly referred to as EA-TEF) ${ }^{1}$ with an estimated incidence of approximately 1 in 3500-4500 live 
births ${ }^{2,3}$.

The trachea and the esophagus share a common embryologic origin from an outgrowth of the foregut, the "lung bud", that appears around the fourth week of gestation. By the end of the fifth week a septum divides it in two parts and it separates from the foregut ${ }^{4}$. The TEF is caused by a defect in the septum that preserves the communication between the esophagus and the lower trachea. Rare variants include a communication between the esophagus and the right main stem bronchus or the connection of the trachea and esophagus at proximal and distal sites by two or even three fistulae ${ }^{5}$.

Repair of the TEF consists of the separation of the esophagus from the trachea and closure of the defect of the tracheal wall. There is usually a visible "ridge" at the site of the repair and often a blind pouch that can be intermittently open (Image 1A). The repair of the esophagus is far more complex, particularly if there is a long gap between the two atretic segments ${ }^{6}$. Despite the repair of the defect, the condition carries a very high morbidity primarily associated with the presence of severe tracheomalacia (TM) or tracheobronchomalacia (TBM). The complications of TEF are most prevalent and severe during the first few years of life but may last in varying degrees throughout life ${ }^{7-18}$.

Improvement in the survival of infants born with EA-TEF has highlighted the need to optimally manage their symptoms, reduce morbidity, and improve quality of life. The International Network on Esophageal Atresia (INoEA), comprised of health professionals involved in the care of children with EA-TEF, published guidelines for the evaluation and treatment of gastrointestinal and nutritional complications in EA-TEF and on the surgical management of long-gap EA $\mathrm{E}^{6,19,20}$. The Respiratory Complications Working Group (RCWG) was formed at the invitation of the INoEA Steering Committee, to develop a similar framework for the management of the respiratory complications of TEF. The RCWG consists of 10 academic Pediatric Pulmonologists from Canada, Italy, Australia, and the USA, with experience in the diagnosis and management of infants and children with EA-TEF.

The document is intended for all health care professionals who are involved in the care of patients with EA-TEF in or outside the hospital setting. It may also be useful for the families of patients with EA-TEF in understanding the rationale behind the multiple diagnostic and therapeutic interventions that may be necessary throughout childhood and adolescence.

\section{METHODS}

The literature on the respiratory complications of TEF is based on small, single institution, retrospective case series and case reports. There are no systematic reviews or randomized controlled trials to formulate evidencebased guidelines on diagnosis and treatment. To address this deficiency the RCWG chose a modification of the RAND Appropriateness Method (RAM) ${ }^{21}$ developed by the RAND Corporation-University of California Los Angeles, that helps synthesize the available empirical evidence using the collective experience of a panel of experts. The RAM approach has been widely used in the development of clinical practice guidelines, including in adult respiratory care ${ }^{22}$, in primary pediatric $\operatorname{care}^{23}$ and in rare pediatric conditions such as Duchenne Muscular Dystrophy ${ }^{24-26}$.

The RAM rates diagnostic and therapeutic interventions on the basis of their "appropriateness" and "necessity". The appropriateness of an intervention is based on its known or expected medical benefit without consideration of any logistical or financial obstacles. Appropriateness does not automatically imply necessity (e.g. bronchoalveolar lavage is an appropriate diagnostic modality for the evaluation of pneumonia, but it is not necessary for every case of pneumonia). The "necessity" is based on whether a) the specific intervention has been deemed appropriate; b) there is reasonable expectation it will benefit the patient in a substantial way; c) according to prevailing standards of care, it would be inappropriate not to offer this intervention to the patient. The RAM enables individual expert opinion to be independently and anonymously expressed and identifies areas of agreement as well as of disagreement or uncertainty that are in need of further study.

The development of the recommendations consisted of the following steps (Figure 1):

Step 1 . Review of the literature andformulation of statements . Questions relating to the domains 
ofRespiratory Physiology (RP), Diagnostic Methods (DM) and Therapeutic Interventions (TI) for the management of respiratory complications in EA-TEF were generated by literature reviews limited to the English language. Each question was subsequently discussed and reformulated into specific statements during a faceto-face meeting. The agreed upon statements were entered into matrices containing clinical scenarios with a list of potential interventions in 3 areas: Respiratory Pathophysiology (RP) Diagnostic Methods (DM) and Therapeutic Interventions (TI).

Step 2. Rating of statements for "appropriateness". All statements were individually rated for appropriateness on an ordinal scale of 1-9 as follows: INAPPROPRIATE: ratings 1-3; UNCERTAIN: ratings 4-6; and APPROPRIATE: ratings 7-9. Pathophysiologic mechanisms were rated as "appropriate" according to the degree to which the statement was supported by generally acknowledged pulmonary physiology, currently available literature, and/or by the clinical experience of the responders. Statements in which all responses were in agreement i.e. within the same category were set aside whilst the remaining statements underwent a second and third round of rating. The results of each round were shared within the RCWG without identifying the responders.

Step 3. Rating of statements for "necessity" . Necessity ratings were applied only to statements pertaining to Diagnostic Methods and Therapeutic Interventions and were rated on an ordinal scale 1-9 as follows: UNNECESSARY: 1-3; UNCERTAIN: 4-6; NECESSARY: 7-9. The median, range and the mean $( \pm \mathrm{SD})$ were calculated. In the final collation, the responses were classified as follows:

- "Strong" agreement : both the median and the mean values of the responses for a given item were within the highest category (7-9)

- "Moderate" agreement : both the median and the mean values of the responses for a given item were within the middle category (4-6)

- "Weak" agreement : The median value was in the lowest category (1-3) and/or the difference between the highest and lowest value was [?] 3.

Step 4 . Formulation of the recommendations. The recommendations were classified as Level A (based on strong agreement), B (moderate agreement) and $\mathrm{C}$ (weak agreement). The ratings on Necessity were formulated into specific recommendations presented in 10 sections (6 for Diagnostic Methods and 4 for Therapeutic Interventions) with their supportive evidence.

\section{RESULTS}

\section{RESPIRATORY PATHOPHYSIOLOGY}

Respiratory complications in TEF are the result of several interacting anatomic and functional abnormalities (Figure 2), and they can be summarized as follows:

1. Tracheomalacia: Tracheomalacia in EA-TEF was identified as the main pathology that causes or predisposes to almost all other respiratory complications. ${ }^{27}$ Tracheomalacia is caused by the anteroposterior collapse of the cartilaginous wall and especially by the intrusion of the posterior trachealis muscle into the lumen. This changes its appearance from the typical "Horseshoe arch" shape, to a flattened "crescent" shape (Images 1B \& 1C). Bronchomalacia is often present as well (Image 1D).

Factors implicated in the development of TM include deficient tracheal cartilage at the level of the fistula, intrinsic cartilage weakness over longer tracheal segments due to in-utero compression from the dilated proximal esophageal pouch ${ }^{14}$ and/or aberrant myoelastic development of the posterior membrane. ${ }^{27-29}$. The lower (intrathoracic) trachea collapses mostly during exhalation, whereas the extrathoracic trachea collapses during inspiration. Further deterioration of the TM may ensue post-repair, from recurrent tracheal inflammation due to aspiration and infection, or due to tracheal wall weakness secondary to prolonged intubation and long-term mechanical ventilation..$^{27,28,30-33}$ Intermittent dilatation of the esophagus due to bolus obstruction can easily overcome the resistance of the weakened tracheal wall and cause its further collapse $\mathrm{e}^{34,35}$. Complications attributed to TM are: 
- Cyanotic spells : Early in infancy, patients can develop severe or even life-threatening airway obstruction associated with profound drops in oxyhemoglobin saturation and bradycardia (colloquially referred to as the TEF "death spells"). ${ }^{34,36,37}$ The episodes tend to occur when there are increases in intrathoracic pressure (e.g. during crying or straining) that cause almost complete collapse of the tracheal lumen ${ }^{37,38}$ The desaturation is more dramatic when there are anatomical communications (e.g. PDA, ASD, VSD) causing right-to-left shunt.

- Chronic cough : A dry barking cough (also described as "honking" or "brassy") is the trademark symptom of TM especially in infancy and childhood; this cough tends to decrease somewhat with age ${ }^{8,18,39}$. A chronic wet cough (often described as "smoker's cough") may develop in early childhood and can remain across the lifespan ${ }^{40,41}$.

- Recurrent lower respiratory tract infections : Multiple episodes of pneumonia-especially during the first few years of life-are reported in as many as $50 \%$ of the children whereas intermittent or chronic bronchitis is reported by almost $2 / 3$ of adults with EA-TEF. ${ }^{9,11,13,15-18,41-46}$ Recurrent lower respiratory tract infections can lead to bronchiectasis, poor lung function, and lower quality of life in adulthood. ${ }^{40,43,47}$

- Chronic or recurrent "wheezing" : Infants and young children with EA-TEF often produce a wheezelike persistent harsh expiratory noise that is often misdiagnosed as "bronchiolitis" or "asthma", or in older patients as exercise induced asthma. The "wheeze" is produced by the collapse of the tracheal lumen and not by bronchospasm and therefore does not respond to bronchodilators. ${ }^{11}$

2. Impaired airway clearance: The narrowing of the tracheal lumen leads to retention of airway secretions whose clearance is further impaired by the loss of cilia on the respiratory epithelial cells at the fistula site $^{28,33,48}$. The retention of secretions predisposes to colonization with bacterial organisms and progressive airway inflammation that may lead to irreversible lung damage, including bronchiectasis. Affected patients are likely to have recurrent or chronic wet cough often termed protracted bacterial bronchitis ${ }^{49-51}$.

3. Aspiration : Recurrent aspiration is the result of anatomical and/or functional abnormalities and it is recognized as a cause or contributing factor of acute and chronic respiratory morbidity in various conditions $^{52-56}$. The anatomical abnormalities consist of direct communications of the tracheobronchial tree and the alimentary tract (such as laryngeal clefts, tracheoesophageal or bronchoesophageal fistulae) and result in direct aspiration ${ }^{12,52,53}$. Direct aspiration can also result when one or both vocal cords are paralyzed in abduction. ${ }^{57}$ The functional causes are due to predisposing conditions that allow liquids or solids near the larynx. Such factors include dysphagia and swallowing impairment (e.g. inability to or delayed bolus formation, pooling of secretions in the pyriform sinuses etc.), GER, and regurgitation of foodstuff that is stuck in the esophagus ${ }^{58-61}$. All of these factors can result in aspiration if the patient is also unable to protect the airways with laryngospasm and/or clear the trachea after laryngeal penetration using cough.

Regardless of the underlying mechanism, aspiration can exacerbate chronic airway inflammation, facilitate the colonization of the airways with bacteria, and expose the infants to allergens at an early age, potentially leading to atopy ${ }^{62}$. The ensuing chronic inflammation and recurrent infections may lead to the development of bronchiectasis and severe impairment of the lung function consisting of lower airway obstruction with air-trapping as well as actual loss of lung volume $e^{53,55,63,64}$.

3. Bronchiectasis: Bronchiectasis is one of the more serious pulmonary complications in patients with EA-TEF ${ }^{9,11,43,65-70}$. Although it is the end-result of other complications (especially recurrent LRTIs and aspiration), it becomes a specific entity by itself, becoming the source of even more infections and causing irreversible damage to the airways. Clinically, it is characterized by daily productive cough (even in the absence of an acute infection). Exacerbations are associated with increased purulent sputum production, frequently fever, dyspnea, and in advanced cases hemoptysis. ${ }^{49,50}$ Because young children cannot expectorate, changes in the quality of the cough from dry to "wet" have been proposed as an alternative to changes in sputum production and appearance ${ }^{47,49,50}$.

4. Gastroesophageal dysmotility: EA-TEF is characterized by multiple functional and anatomical gastro- 
esophageal abnormalities that have been discussed in detail elsewhere. ${ }^{19,59}$ In general, these abnormalities tend to be contributing or predisposing factors to the development of respiratory complications from the upper and/or lower airways. ${ }^{58-61}$ Gastroesophageal reflux and/or esophageal regurgitation can cause chronic laryngeal irritation that may manifest itself as recurrent stridor and/or chronic hoarseness. ${ }^{9,53,58,71}$ However, chronic stridor, especially if it is not accompanied by difficulty in breathing, should raise suspicions of vocal cord paralysis due to trauma of the recurrent laryngeal nerve during the repair ${ }^{57,72}$. Effects in the lower airways include tracheal compression from a dilated esophagus, and conditions that increase the risk of aspiration such as regurgitation, impaired swallow, and GER.

5. Associated congenital abnormalities. Although EA-TEF can be an isolated abnormality, in about $50 \%$ of patients it is part of syndromes involving multiple other organ-systems ${ }^{3,73}$. The most common include the VACTERL association (vertebral defects, anal atresia, cardiac defects, TEF, renal anomalies, and limb abnormalities), the CHARGE syndrome (coloboma, heart defects, atresia choanae, growth retardation, genital abnormalities, and ear abnormalities) and chromosomal abnormalities (including Down syndrome). Of special interest are associated abnormalities of the upper airways ${ }^{74-77}$ as well as various cardiovascular anomalies $^{78-84}$. All of these conditions increase the morbidity and, in the case of congenital heart disease, the mortality as well ${ }^{85}$.

\section{B. RECOMMENDATIONS ON DIAGNOSTIC METHODS}

\section{Evaluation of Tracheobronchomalacia}

Level A Recommendations Recommendation 1: Flexible bronchoscopy is the gold standard for the evaluation of TB] Level B Recommendations Recommendation 5: Multi-detector CT scan is an accurate method of assessing TBM Re Level C Recommendations Recommendation 7: Tidal flow-volume loops are a reliable way of assessing the severity o

Flexible bronchoscopy is considered the gold standard for the evaluation of the presence and severity of TBM. Rigid bronchoscopy tends to underestimate the degree of the tracheal collapse because it "stents" the airway $^{51,86-88}$.

There was moderate agreement regarding the use of standard chest CT because it may not capture the dynamic changes of the tracheobronchial lumen that occur during the respiratory cycle (especially with cough). Inspiratory and expiratory dynamic multi-detector chest CT scans were considered superior because they are fast, relatively inexpensive, and provide additional and detailed information about the airways, the lung parenchyma, and the thoracic vasculature ${ }^{51,87,89,90}$. However, at the moment they may not be available in every hospital.

Maximal expiratory flow-volume curves (MEFVCs) can be often diagnostic of tracheomalacia ${ }^{91}$, showing a characteristic flattening of the initial portion of the MEFVC (Figure 3A). Its disadvantage is that it can only be performed in children over 4-5 years of age, and it becomes less sensitive in older children and adolescents ${ }^{44,92}$. Infants can be evaluated with the raised-volume rapid thoracoabdominal compression (RVRTC) technique, which allows the performance of MEFVCs without the patient's cooperation but is labor intensive and usually requires sedation ${ }^{93}$. An alternative easy, non-invasive technique to evaluate flowlimitation is with tidal flow volume $\operatorname{loops}^{94}$ (Figure 3B). However, it is not well standardized, and it may miss mild/moderate TBM.

\section{Evaluation of a Recurrent Tracheoesophageal Fistula}

Level A Recommendations Recommendation 8: Combined endoscopy and bronchoscopy are the gold standard for th Level C Recommendations Recommendation 9: Barium swallow in prone/semi-prone position is the preferred radiog

Recurrent TEFs occur in 5-10\% of cases after primary repair, as a result of esophageal anastomotic leak, trauma from esophageal dilatations and/or airway infections ${ }^{95-102}$. The manifestations of recurrent TEF 
are potentially severe and include cough, choking and cyanosis during feeds, and recurrent pneumonias. Diagnosis is challenging and often delayed despite multiple investigations. There was strong agreement that recurrent TEFs are best diagnosed with simultaneous esophageal endoscopy and bronchoscopy, aided by the infusion of methylene blue on the tracheal or esophageal side and observing its appearance on the other side $^{98,103}$. An esophagogram in prone or semi-prone position with contrast administered under pressure can be diagnostic and has the fewest false negative results (compared with upper GI in supine or erect positions), but it may miss a TEF in the presence of an esophageal stricture ${ }^{95,97,104,105}$. Moreover, it is not a standard technique among radiologists, and therefore did not receive strong recommendation. This multidisciplinary approach is increasingly used to optimise outcomes in children with recurrent $\mathrm{TEF}^{106,107}$.

\section{Evaluation of Bronchitis and Pneumonia}

Level A Recommendations Recommendation 11: The presence of a chronic wet cough requires further evaluation Re Level B Recommendations Recommendation 16: Pneumonia in patients with EA/TEF should be confirmed by CXR Level C Recommendations Recommendation 17: The threshold for obtaining CXR should be low because pneumoni

Based on the high risk for recurrent episodes of bronchitis and/or pneumonia in EA-TEF, the RCWG strongly recommended that chronic wet cough should be evaluated for underlying undiagnosed anatomic and/or functional abnormalities. The main evaluation includes a CT scan to determine the presence of chronic changes such as bronchiectasis ${ }^{47,50}$, and a BAL to determine presence of colonization with bacterial and other pathogens as well as for evidence of aspiration(see also section $\mathrm{V}$ for the evaluation of aspiration). The threshold for repeating the investigations should be low because there is evidence that airway inflammation, bacterial bronchitis, and bronchiectasis may be present in young children with EA/TEF even when they are asymptomatic ${ }^{9,45,65,107,108}$. However, for patients with an established pattern it is not necessary to repeat the work-up for every exacerbation unless there is suspicion of new pathology. A CXR with each suspected episode of pneumonia may be useful to document how often a patient is having lobar pneumonia, which may, in turn, determine the necessity for further investigations.

\section{Evaluation of Bronchiectasis}

Level A Recommendations Recommendation 23: A negative CXR does not rule out the presence of bronchiectasis $\mathbf{R}$ Level C Recommendations Recommendation26: CXR should be obtained annually in all children with TEF regardle Bronchiectasis is defined as an abnormal dilatation of the bronchial tree and it is one of the more serious pulmonary compli Evaluation of Possible Aspiration

Level A Recommendations Recommendation 29: Multiple episodes of lobar pneumonia should be evaluated for aspir Level B Recommendations Recommendation 30: BAL is indicated in cases of suspected aspiration

Level C Recommendations Recommendation 31: Asymptomatic children with EA/TEF who have positive cultures i Patients with EA-TEF are predisposed to aspiration and the possibility should be investigated in cases of recurrent pneumc VI. Evaluation of Cyanosis

Level A Recommendations Recommendation 36: An echocardiogram should be performed in infants with EA-TEF v Level B Recommendations Recommendation 37: Chest CT with contrast should be performed when a vascular anon

Intermittent acute profound cyanosis in patients with EA-TEF is usually due to near complete collapse of the trachea. However, the possibility of an anatomical shunt has to be ruled out because congenital heart malformations associated with right-to-left shunts (such as valve atresia, Tetralogy of Fallot, anomalous pulmonary venous return, and septal defects or patent ductus arteriosus) are present in more than one quarter of the patients ${ }^{80,84}$ and they are independent predictors of survival ${ }^{125}$. For children with no history of congenital heart disease an echocardiogram is useful in order to investigate for presence of vascular abnormalities such as right-sided or double aortic arch, and aberrant right or left subclavian arteries that may complicate the clinical presentation by causing or exacerbating the degree of tracheomalacia ${ }^{37,78,80,81,126}$. Definitive confirmation will require a CT-angiogram or an MRI/MRA or cardiac catheterization. 


\section{RECOMMENDATIONS ON THERAPEUTIC INTERVENTIONS}

\section{Management of Tracheobronchomalacia}

Level A Recommendations Recommendation 1: Non-invasive Positive Pressure Ventilation is useful in children with Level B Recommendations Recommendation 4: Aortopexy is a safe \& effective way to treat severe TBM Recomme

Infants with mild TM can be successfully extubated after the repair of the EA-TEF and do not require any ventilatory or other support. They often remain symptomatic with recurrent or persistent symptoms (such as "barking" cough and coarse wheeze), which tend to be amplified during episodes of upper and/or lower respiratory tract infections. Tracheomalacia tends to improve over time due to the increase in diameter of the tracheal lumen and a reduction in airway collapsibility that minimize the degree of obstruction relative to lumen size. However, it is a slow process that even under the best circumstances continues for years.

Patients with severe (especially extensive) tracheomalacia (with or without bronchomalacia) may have severe, potentially life-threatening symptoms due to the almost complete tracheal collapse, and they are likely to require some type of ventilatory support ${ }^{127-130}$. Such support is usually needed immediately after extubation following the surgical repair of the EA-TEF, but may be needed for weeks or months afterwards. Patients without lung disease and/or respiratory muscle weakness respond well to non-invasive positive airway pressure (continuous positive airway pressure (CPAP) or Bi-Level Positive Airway Pressure (PAP)) that prevents the complete collapse of the tracheal lumen. High flow nasal cannula (HFNC) is a newer modality that has been shown to be effective and safe ${ }^{71,131-133}$.

There is concern that non-invasive PAP in the immediate post-repair period increases the risk of air leak in the area of the repaired TEF, or damage to the esophageal anastomosis ${ }^{134}$. However, in practice the various forms of PAP/HFNC have been used safely ${ }^{135}$ and the RCWG felt that the risk of respiratory decompensation in the immediate post-operative period, outweighs the theoretical risks of non-invasive PAP. The situation is more problematic for infants who may need prolonged continuous support because in many countries (including the US) the non-invasive types of ventilation are not approved for continuous use in the home environment.

Aortopexy has been used successfully for TM due to compression of the anterior tracheal wall (e.g. compression by the innominate artery $)^{136}$. However, in EA-TEF the tracheal occlusion is caused mostly by the intrusion of the posterior tracheal wall into the tracheal lumen. Thus a posterior tracheopexy (pulling of the posterior tracheal membrane with sutures that are secured onto the anterior longitudinal spinal ligament) has been suggested as a more definitive treatment. The technique has been modified to include aortopexy of the descending aorta that is often causing severe compression of the posterior wall of the left main stem bronchus $36,71,100,127,136-140$. These techniques are still very much dependent on specific surgical and institutional expertise and the evidence about their long-term effectiveness is still scant. Even the timing of the procedure varies, with some centers performing these procedures at the time of the initial repair of the EA-TEF, while other consider them only for severe persisting malacia not responding to non-invasive PAP. Thus, they did not receive a strong recommendation by the RCWG. However, it was recognized that they could become the standard of care in the future.

For patients who have repeated, life threatening cyanotic episodes despite non-invasive PAP, and are not candidates for surgical repair, a tracheostomy provides a secure airway that can be used with or without positive pressure support ${ }^{141}$. Because most TEFs are located near the carina, a regular tracheostomy tube that extends only to the middle trachea may not prevent the collapse of the lower trachea. Therefore a custom made tube that extends to the lower trachea may be necessary (these tubes may also provide enough stenting of the main stem bronchii) ${ }^{142}$.

The use of tracheal (and/or bronchial) stents for the management of severe TBM was recently reviewed by the European Respiratory Society ${ }^{143}$. Theoretically, stents would be the "ideal" solution to the problem of severe TBM. However, they are rarely used in infants because of lack of size-appropriate stents, stent 
migration, difficulty of removal, and most importantly, because of the need to replace them with a bigger stent as the trachea grows.

Bethanecol is a synthetic muscarinic stimulant that has been used in certain cases of tracheomalacia. Stimulation of the muscarinic receptors in the airways should normally produce bronchospasm, but it seems to actually "open" an airway that is floppy due to malacia by increasing the trachealis muscle tone. There are no RCTs on its use but in a small series it appeared to be safe ${ }^{144}$.

\section{Antibiotic Therapy}

Level A Recommendations Recommendation 7: The threshold for considering antibiotics should be lower in children Level B Recommendations Recommendation 9: Antibiotic therapy is indicated for asymptomatic children with posit Level C Recommendations Recommendation 11. Antibiotics should be given only in patients who are febrile and hav

The retention of secretions due to poor airway clearance, and the high prevalence of recurrent, aspiration that promotes the colonization of the lower airways with organisms from the oropharynx, predispose children with EA-TEF to recurrent LTRIs ${ }^{9,12,17,145}$. There was strong agreement that these factors justify the lower threshold for initiating antibiotics with the development of symptoms such as increased "wet" cough (even without fever) or when cultures from BAL are positive for bacterial pathogens even in the absence of symptoms.

Borrowing primarily from the experience in patients with Cystic Fibrosis ${ }^{146-148}$, there was strong agreement on the use of prophylactic azithromycin due to its antimicrobial and anti-inflammatory properties for patients with chronic symptoms, especially those with documented bronchiectasis ${ }^{149,150}$. However, there was only moderate agreement on using antibiotics in asymptomatic children who have positive BAL cultures especially with organisms are considered to be "normal" oral flora.

There are no systematic studies on the exact organisms that may colonize the airways of patients with EA-TEF, but it is reasonable to assume that they are colonized by the same organisms found in children without EA-TEF who have chronic wet cough (such as Haemophilus influenzae, Staphylococcus aureus and Streptococcus pneumoniae, Moraxella Catarrhalis) ${ }^{50,70,111}$, as well as anaerobic organisms due to possible aspiration. Most of these organisms are usually sensitive to amoxicillin/clavulanic acid that is recommended for the treatment of chronic cough ${ }^{151}$.

\section{Health Maintenance and Prevention}

Level A Recommendations Recommendation 12: Children with EA-TEF should be followed by a specialized interdis Level B Recommendations Recommendation 16: Anti-RSV prophylaxis is indicated for infants with EA/TEF under

Historically, patients with EA-TEF had little follow-up by specialists once they recovered from the initial repair. However, longitudinal studies in adult survivors of EA-TEF highlighted the high prevalence of respiratory complications across the lifespan ${ }^{44,46}$. Early detection and management of respiratory complications may prevent irreversible structural lung disease and loss of lung function ${ }^{11,16,18,152}$.

The RCWG strongly recommends systematic follow-up by multidisciplinary teams that include pulmonologists, gastroenterologists, otolaryngologists, pediatricians and thoracic surgeons, as well as dieticians, physiotherapists, speech-language pathologists or occupational therapists, and social workers ${ }^{2,19,20,107,124,153-155}$. Some centres have also included diagnostic and interventional radiologists and an intensivist ${ }^{156}$. Special emphasis is given to have regular evaluation and follow-up by psychologists because of growing concern about the long-term effect of EA-TEF on the quality of life of the patients and their families ${ }^{157-160}$.

This approach allows the timely identification of multisystem treatable abnormalities, better care coordination and increase safety by reducing the number of exposure to general anesthesia ${ }^{152}$. For the family, it 
decreases the number of visits to the hospital and the associated facility charges. This results into higher family satisfaction, while it remains cost effective for the hospitals ${ }^{106,161,162}$.

The RCWG strongly agreed that patients with EA-TEF should receive all recommended mandatory vaccinations as well as the annual influenza vaccine. There was only moderate agreement on the need for RSV prophylaxis possibly reflecting different policies that exist in each country regarding this intervention.

How often the patients need to be evaluated by the entire team depends on the special needs of the patients and the feasibility of assembling such a large team in each institution ${ }^{158}$. Acknowledging that such a team may not be feasible in smaller institutions, let alone in clinics or doctors' offices, the RCWG developed a list of the essential elements for the follow-up of patients with EA-TEF (Tables 1A, 1B \& 2)

\section{Adjunct Therapies}

Level A Recommendations Recommendation 18: Airway clearance techniques should be instituted in asymptomatic Level B Recommendations Recommendation 19: A trial of medical anti-GER therapy is useful in children with persi Level C Recommendations Recommendation 21: Mucolytics should be used routinely to facilitate airway clearance $\mathbf{F}$

Virtually all therapies used in patients with EA-TEF are directed to specific problems/symptoms and are based on empiric evidence. The RCWG rated the following:Airway Clearance: There was strong agreement that age appropriate airway clearance techniques (e.g. manual chest physiotherapy, High Frequency Chest Wall Oscillation, Positive Expiratory Pressure valve) should be used routinely to aid the clearance of secretions. There are no studies comparing these techniques in the EA-TEF population (or in tracheomalacia in general). Therefore, the selection relies on the availability of the various devices, and on institutional practices ${ }^{163-165}$. The Positive Expiratory Pressure valve technique may be particularly helpful in patients with tracheomalacia and/or bronchiectasis, by stenting collapsible airways open and aid airway clearance ${ }^{166}$. Anti-GE Reflux therapy: The association of GER with respiratory morbidity and the effectiveness of empiric anti-GER treatment remain highly controversial ${ }^{58,61,167}$. This is in part, due to the fact that respiratory symptoms from the upper and/or from the lower airways can be caused by miniscule amounts of refluxate and as a result the usual diagnostic studies for GERD may likely be within the normal range. The RCWG did not address in detail the management of GER, GERD and aspiration because they have been recently reviewed in detail in the INoEA Consensus Guidelines on Gastrointestinal Complications of EA-TEF ${ }^{19,167}$. However, a moderate agreement was reached on trying empirically anti-GER therapy for patients with persistent respiratory symptoms based primarily on the fact that the prevalence of GER is

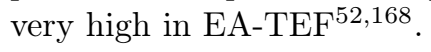

Bronchodilators : The use of bronchodilators in EA-TEF remains controversial. On one hand there is evidence of increased airway hyperreactivity among patients with EA-TEF that warrants the use of bronchodilators ${ }^{15,68}$. Albuterol is also being used to improve mucociliary clearance ${ }^{169}$. On the other hand, chronic "wheezing" in patients with EA-TEF is often caused by the collapse of the tracheal lumen that cannot be prevented or reversed with bronchodilators. Moreover, the overrelaxation of the tracheobronchial smooth muscle may actually worsen the obstruction (Figure $3 \mathrm{~A})^{170}$. Thus, although, a trial with bronchodilators for symptomatic children is warranted, the RCWG does not recommend $\beta_{2}$-agonists as standard therapy for EA-TEF. However, ipratropium bromide (an anticholinergic agent) has been shown to be associated with improved symptoms in children with TM (possibly due to decreased effect on the tracheobronchial muscle tone and/or by reducing the amount of secretions) and it may be considered as an alternative of albuterol ${ }^{171}$..

Inhaled corticosteroids (ICS) : The role of steroids in TBM is rather controversial and there was weak agreement on their routine use because the inflammation in EA-TEF tends to be neutrophilic and therefore less likely to respond to steroids ${ }^{63}$. Furthermore, there is some evidence that chronic use of high doses of ICS may actually cause or exacerbate existing tracheomalacia ${ }^{172}$. Thus of the routine use of ICS should be reserved for documented or highly suspected airway hyperreactivity.

Mucolytics : Mucolytic agents (Dornase alpha, hypertonic saline, N-Acetylcysteine) are often used in 
patients with tracheomalacia on the assumption that the impaired airway clearance probably results in the accumulation and possibly thickening of secretions. Dornase alpha and hypertonic saline are commonly used in the management of cystic fibrosis-related chronic bronchiectasis, but their effect in non-CF bronchiectasis is not as well defined ${ }^{173}$. Thus, the RCWG did not support its routine use.

\section{DISCUSSION}

Guidelines are intended to review systematically the available evidence, rate its validity, and distill the findings into easy to understand recommendations that practitioners can follow. Many different methodologies have been developed for this purpose ${ }^{21,174,175}$ The GRADE method (Grading of Recommendations Assessment, Development and Evaluation ${ }^{175}$, has been recently adopted by a number of professional organizations for the development of guidelines, but we did not choose it because it relies heavily on RCTs and systematic observational studies that are not available in the literature on EA-TEF.

We developed our recommendations on the basis of the Rand Appropriateness Method ${ }^{24-26}$, offered certain important advantages for the type of evidence we had available such as: a) the responders do not have to accept positions they do not agree with, in order to reach a consensus; b) disagreements are not suppressed, thus reflecting more accurately the uncertainties and variability that exist in the actual clinical practice; c) each item is rated by all responders, and their responses carry the same weight (thus preventing a single issue (or a single person) from dominating the process; $\mathrm{d}$ ) the anonymity of the responses allows the participants to express their opinions more freely; and e) it provides timely feedback by communicating the results of each round to the responders, allowing them to compare their responses to others and potentially adjust them.

Our recommendations were based on the strength of the agreement among the RCWG members. Thus, Level A recommendations refer to unanimous adoption of specific interventions and care practices. Level B \& $\mathrm{C}$ recommendations reflect both the lack of evidence and actual controversies on a specific topic, as well as the different areas of expertise, skill mix, resource availability and hospital culture among the RCWG's representative institutions. This differs from other consensus based methods that assign different weight on the evidence depending on the design of the study, its size, the type of analysis etc. $)^{176}$.

As diagnostic methods improve and therapeutic interventions become more precise, it is likely that many of the current recommendations will have to be revised. In the meantime, the document provides a common approach for the evaluation and management of these complex patients at levels that can be provided by most practitioners and institutions. It may also serve as the basis for multicenter collaborations that will eventually provide a higher level of evidence.

\section{ACKNOWLEDGMENTS}

The authors would like to acknowledge the contribution of Dr. Michael Rutter and Dr. Marlene Soma for their input in the development of the original statements. We would also like to thank Drs. Frederic Gottrand, Christophe Faure, Luigi dall' Oglio, and Usha Krishnan for their critical review of the manuscript.

\section{REFERENCES}

1. Billmyre KK, Hutson M, Klingensmith J. One shall become two: Separation of the esophagus and trachea from the common foregut tube. Dev Dyn 2015;244(3):277-288.

2. Cassina M, Ruol M, Pertile R, Midrio P, Piffer S, Vicenzi V, Saugo M, Stocco CF, Gamba P, Clementi M. Prevalence, characteristics, and survival of children with esophageal atresia: A 32-year population-based study including 1,417,724 consecutive newborns. Birth Defects Res Part A Clin Mol Teratol 2016;106(7):542548.

3. Lupo PJ, Isenburg JL, Salemi JL, Mai CT, Liberman RF, Canfield MA, Copeland G, Haight S, Harpavat S, Hoyt AT, et al. Population-based birth defects data in the United States, 2010-2014: A focus on gastrointestinal defects. Birth Defects Res 2017;109(18):1504-1514. 
4. Fausett SR, Klingensmith J. Compartmentalization of the foregut tube: Developmental origins of the trachea and esophagus. Wiley Interdiscip Rev Dev Biol 2012;1(2):184-202.

5. Kane TD, Atri P, Potoka DA. Triple fistula: management of a double tracheoesophageal fistula with a third H-type proximal fistula. J Pediatr Surg 2007;42(6):e1-e3.

6. van der Zee DC, Bagolan P, Faure C, Gottrand F, Jennings R, Laberge JM, Martinez Ferro MH, Parmentier B, Sfeir R, Teague W. Position paper of INoEA working group on long-gap Esophageal Atresia: For better care. Front Pediatr 2017;5.

7. Acher C, Ostlie D, Leys C, Struckmeyer S, Parker M, Nichol P. Long-Term Outcomes of Patients with Tracheoesophageal Fistula/Esophageal Atresia: Survey Results from Tracheoesophageal Fistula/Esophageal Atresia Online Communities. Eur J Pediatr Surg 2015;26(06):476-480.

8. Fragoso AC, Tovar JA. The multifactorial origin of respiratory morbidity in patients surviving neonatal repair of esophageal atresia. Front Pediatr 2014;2:39.

9. Porcaro F, Valfré L, Aufiero LR, Dall'Oglio L, De Angelis P, Villani A, Bagolan P, Bottero S, Cutrera R. Respiratory problems in children with esophageal atresia and tracheoesophageal fistula. Ital J Pediatr 2017;43(1):77.

10. Sulkowski JP, Cooper JN, Lopez JJ, Jadcherla Y, Cuenot A, Mattei P, Deans KJ, Minneci PC. Morbidity and mortality in patients with esophageal atresia. Surgery 2014;156(2):483-91.

11. Kovesi T. Long-term respiratory complications of congenital esophageal atresia with or without tracheoesophageal fistula: an update. Dis Esophagus 2013;26(4):413-416.

12. Kovesi T, Rubin S. Long-term Complications of Congenital Esophageal Atresia and/or Tracheoesophageal Fistula. Chest 2004;126(3):915-925.

13. Lacher M, Froehlich S, von Schweinitz D, Dietz HG. Early and Long Term Outcome in Children with Esophageal Atresia Treated Over the Last 22 Years. Klin Pädiatrie 2010;222(05):296-301.

14. Leibovitch L, Zohar I, Maayan-Mazger A, Mazkereth R, Strauss T, Bilik R. Infants Born with Esophageal Atresia with or without Tracheo-Esophageal Fistula: Short- and Long-Term Outcomes. Isr Med Assoc J 2018;20(3):161-166.

15. Malstrom K, Lohi J, H L, Pelkonen A, Kajosaari M, Sarna S, Malmberg LP, makela mika j. Longitudinal Follow-up of Bronchial Inflammation, Respiratory Symptoms, and Pulmonary Function in Adolescents after Repair of Esophageal Atresia with Tracheoesophageal Fistula. J Pediatr 2008;153:396-401.

16. Mirra V, Maglione M, Di Micco LL, Montella S, Santamaria F. Longitudinal Follow-up of Chronic Pulmonary Manifestations in Esophageal Atresia: A Clinical Algorithm and Review of the Literature. Pediatr Neonatol 2017;58(1):8-15.

17. Nurminen P, Koivusalo A, Hukkinen M, Pakarinen M. Pneumonia after Repair of Esophageal AtresiaIncidence and Main Risk Factors. Eur J Pediatr Surg 2019;29(6):504-509.

18. Patria MF, Ghislanzoni S, Macchini F, Lelii M, Mori A, Leva E, Principi N, Esposito S. Respiratory morbidity in children with repaired congenital esophageal atresia with or without tracheoesophageal fistula. Int J Environ Res Public Health 2017;14(10):1-13.

19. Krishnan U, Mousa H, Dall'Oglio L, Homaira N, Rosen R, Faure C, Gottrand F. ESPGHAN-NASPGHAN guidelines for the evaluation and treatment of gastrointestinal and nutritional complications in children with esophageal atresia-tracheoesophageal fistula. J Pediatr Gastroenterol Nutr 2016;63(5):550-570.

20. Mousa H, Krishnan U, Hassan M, Dall'Oglio L, Rosen R, Gottrand F, Faure C. How to Care for Patients with EA-TEF: The Known and the Unknown. Curr Gastroenterol Rep 2017;19(12):65. 
21. Fitch K, Bernstein S, Aguilar MD, Burnand B, LaCalle JR, Lazaro P, van het Loo M, McDonnell J, Vader J, Kahan JP. The Rand/UCLA appropriateness method user's manual. The RAND/U. Santa Monica: Rand; 2001.

22. Verburg AC, van Dulmen SA, Kiers H, Ypinga JHL, Nijhuis-van der Sanden MWG, van der Wees PJ. Development of a standard set of outcome domains and proposed measures for chronic obstructive pulmonary disease in primary care physical therapy practice in the netherlands: Amodified RAND/UCLA appropriateness method. Int J COPD 2019;14:2649-2661.

23. Ewald DA, Huss G, Auras S, Caceres JRC, Hadjipanayis A, Geraedts M. Development of a core set of quality indicators for paediatric primary care practices in Europe, COSI-PPC-EU. Eur J Pediatr 2018;177(6):921-933.

24. Bushby K, Finkel R, Birnkrant DJ, Case LE, Clemens PR, Cripe L, Kaul A, Kinnett K, McDonald C, Pandya S, et al. Diagnosis and management of Duchenne muscular dystrophy, part 1: diagnosis, and pharmacological and psychosocial management. Lancet Neurol 2010;9(1):77-93.

25. Bushby K, Finkel R, Birnkrant DJ, Case LE, Clemens PR, Cripe L, Kaul A, Kinnett K, McDonald C, Pandya S, et al. Diagnosis and management of Duchenne muscular dystrophy, part 2: implementation of multidisciplinary care. Lancet Neurol 2010;9(2):177-189.

26. Birnkrant DJ, Bushby KMD, Amin RS, Bach JR, Benditt JO, Eagle M, Finder JD, Kalra MS, Kissel JT, Koumbourlis AC, et al. The respiratory management of patients with Duchenne muscular dystrophy: A DMD care considerations working group specialty article. Pediatr Pulmonol 2010;45(8):739-48.

27. Davies M, Cywes S. The Flaccid Trachea and Tracheoesophageal Congenital Anomalies. J Pediatr Surg 1978;13(4):363-7.

28. Emery JL, Haddadin AJ. Squamous epithelium in the respiratory tract of children with tracheooesophageal fistula, and "retention lung". Arch Dis Child 1971;46((250)):884.

29. Pole RJ, Qi BQ, Beasley SW. Abnormalities of the tracheal cartilage in the rat fetus with tracheooesophageal fistula or tracheal agenesis. Pediatr Surg Int 2001;17(1):25-28.

30. Austin J, Ali LT. Tracheomalacia and bronchomalacia in children: pathophysiology, assessment, treatment and anaesthesia management. Pediatr Anesth 2003;13(1):3-11.

31. Briganti V, Oriolo L, Buffa V, Garofalo S, Cavallaro S, Calisti A. Tracheomalacia in oesophageal atresia: morphological considerations by endoscopic and CT study. Eur J Cardio-Thoracic Surg 2005;28(1):11-15.

32. Petit L-M, Righini F, Ezri J, Jantchou P, Aspirot A, Soglio D, Faure C. Prevalence and Predictive Factors of Histopathological Complications in Children with Esophageal Atresia. Eur J Pediatr Surg 2019;29(6):510515.

33. Maeta T, Fujiwara Y, Ohizumi T, Nato E, Kakizaki G, Ishidate T, Fujiwara T. Pathological Study of Tracheal and Pulmonary Lesions in Autopsy Cases of Congenital Esophageal Atresia. 1977.

34. Filler RM, Rossello PJ, Lebowitz RL. Life-threatening anoxic spells caused by tracheal compression after repair of esophageal atresia: Correction by surgery. J Pediatr Surg 1976;11(5):739-48.

35. Sekmenli T, Ciftci I, Sivri M, Koplay M. Short-gap Isolated Esophageal Atresia Causing Stridor Due to Compression of the Trachea. Med Arch (Sarajevo, Bosnia Herzegovina) 2015;69(6):425-427.

36. Bairdain S, Smithers CJ, Hamilton TE, Zurakowski D, Rhein L, Foker JE, Baird C, Jennings RW. Direct tracheobronchopexy to correct airway collapse due to severe tracheobronchomalacia: Short-term outcomes in a series of 20 patients. J Pediatr Surg 2015;50(6):972-977.

37. Bergeron M, Cohen AP, Cotton RT. The management of cyanotic spells in children with oesophageal atresia. Front Pediatr 2017;5(May):1-7. 
38. Robert F, Rossello PJ, Lebowitz RL. Life-threatening anoxic spells -Correction by Surgery. J Pediatr Surg 1976;11(5).

39. Fraga JC, Jennings RW, Kim PCW. Pediatric tracheomalacia. Semin Pediatr Surg 2016;25(3):156-64.

40. Sistonen S, Malmberg P, Malmström K, Haahtela T, Sarna S, Rintala RJ, Pakarinen MP. Repaired oesophageal atresia: respiratory morbidity and pulmonary function in adults. Eur Respir J 2010;36(5):110612.

41. Gatzinsky V, Jönsson L, Ekerljung L, Friberg L-G, Wennergren G. Long-term respiratory symptoms following oesophageal atresia. Acta Paediatr 2011;100(9):1222-1225.

42. Pedersen RN, Markøw S, Kruse-Andersen S, Qvist N, Gerke O, Husby S, Agertoft L. Long-term pulmonary function in esophageal atresia-A case-control study. Pediatr Pulmonol 2017;52(1):98-106.

43. Dittrich R, Stock P, Rothe K, Degenhardt P. Pulmonary outcome of esophageal atresia patients and its potential causes in early childhood. J Pediatr Surg 2017;52(8):1255-1259.

44. Chetcuti P, Phelan PD, Greenwood R. Lung function abnormalities in repaired oesophageal atresia and tracheo-oesophageal fistula. Thorax 1992;47(12):1030-1034.

45. Somppi E, Tammela O, Ruuska T, Rahnasto J, Laitinen J, Turjanmaa V, Järnberg J. Outcome of patients operated on for esophageal atresia: 30 years' experience. J Pediatr Surg 1998;33(9):1341-1346.

46. Sistonen SJ, Koivusalo A, Nieminen U, Lindahl H, Lohi J, Kero M, Kärkkäinen PA, Färkkilä MA, Sarna S, Rintala RJ, et al. Esophageal morbidity and function in adults with repaired esophageal atresia with tracheoesophageal fistula: a population-based long-term follow-up. Ann Surg 2010;251(6):1167-73.

47. Gilchrist FJ. An approach to the child with a wet cough. Paediatr Respir Rev 2019;31:75-81.

48. Wailoo M, Emery JL. The trachea in children with tracheo-oesophageal fistula. Histopathology 1979;3(4):329-338.

49. Chang A, JT G, Eastburn M, Faogali J, Cox N, Masters IB. Cough quality in children: A comparison of subjective vs. bronchoscopic findings. Respir Res 2005;6:3.

50. Chang A, A B, Grimwood K. Bronchiectasis in children: diagnosis and treatment. Lancet 2018;392(10150):866-879.

51. Wallis C, Alexopoulou E, Anton-pacheco J, Al. E. ERS statement on tracheomalacia and bronchomalacia in children. Eur Respir J 2019;54:1900382.

52. Wallis C, Ryan M. Assessing the Role of Aspiration in Pediatric Lung Disease. Pediatr Allergy Immunol Pulmonol 2012;25(3):132-142.

53. Kovesi T. Aspiration risk and respiratory complications in patients with esophageal atresia. Front Pediatr 2017;5:62.

54. Hunt EB, Ward C, Power S, Sullivan A, Pearson JP, Lapthorne S, O'Byrne PM, Eustace J, Plant BJ, Maher MM, et al. The Potential Role of Aspiration in the Asthmatic Airway. Chest 2017;151(6):1272-1278.

55. Hunt EB, Sullivan A, Galvin J, MacSharry J, Murphy DM. Gastric Aspiration and Its Role in Airway Inflammation. Open Respir Med J 2018;12(1):1-10.

56. Clarke D, Gorman I, Ringholz F, McDermott M, Cox D, Greally P, Linnane B, Mc Nally P. Pulmonary aspiration in preschool children with cystic fibrosis. Respir Res 2018;19:255.

57. Kovesi T, Porcaro F, Petreschi F, Trozzi M, Bottero S, Cutrera R. Vocal cord paralysis appears to be an acquired lesion in children with repaired esophageal atresia/tracheoesophageal fistula. Int J Pediatr Otorhinolaryngol 2018;112:45-47. 
58. De Benedictis FM, Bush A. Respiratory manifestations of gastro-oesophageal reflux in children. Arch Dis Child 2018;103(3):292-296.

59. Faure C, Grunder FR. Dysmotility in esophageal atresia: Pathophysiology, characterization, and treatment. Front Pediatr 2017;5(May):1-6.

60. Gottrand M, Michaud L, Sfeir R, Gottrand F. Motility, digestive and nutritional problems in Esophageal Atresia. Paediatr Respir Rev 2016;19:28-33.

61. Ambartsumyan L, Nurko S, Rosen R. Gastrointestinal Dysmotility and the Implications for Respiratory Disease. Curr Treat Options Pediatr 2019;5(2):197-214.

62. Mishra A, Hogan SP, Brandt EB, Rothenberg ME. An etiological role for aeroallergens and eosinophils in experimental esophagitis. J Clin Invest 2001;107(1):83-90.

63. De Baets F, De Schutter I, Aarts C, Haerynck F, Van Daele S, De Wachter E, Malfroot A, Schelstraete P. Malacia, inflammation and bronchoalveolar lavage culture in children with persistent respiratory symptoms. Eur Respir J 2012;39(2):392-395.

64. LeSouëf PN, Myers NA, Landau LI. Etiologic factors in long-term respiratory function abnormalities following esophageal atresia repair. J Pediatr Surg 1987;22(10):918-22.

65. Banjar H. Bronchiectasis following repair of esophageal atresia and tracheo-esophageal fistula. Saudi Med J 2005;26(10):1661-2.

66. BEHNIA M, TARVER RD. Unilateral Bronchiectasis and Esophageal Dysmotility in Congenital Adult Tracheoesophageal Fistula. Intern Med 2001;40(7):620-623.

67. Delacourt C, de Blic J. Pulmonary Outcome of Esophageal Atresia. J Pediatr Gastroenterol Nutr 2011;52:S31-S32.

68. Gilley SK, Stenbit AE, Pasek RC, Sas KM, Steele SL, Amria M, Bunni MA, Estell KP, Schwiebert LM, Flume $\mathrm{P}$, et al. Deletion of airway cilia results in noninflammatory bronchiectasis and hyperreactive airways. Am J Physiol - Lung Cell Mol Physiol 2014;306(2):1-18.

69. Imam JS, Duarte AG. Non-CF bronchiectasis: Orphan disease no longer. Respir Med 2020;166(November 2019):105940.

70. Kapur N, Masters IB, Chang AB. Exacerbations in noncystic fibrosis bronchiectasis: Clinical features and investigations. Respir Med 2009;103(11):1681-1687.

71. Tytgat SHAJ, van Herwaarden-Lindeboom MYA, van Tuyll van Serooskerken ES, van der Zee DC. Thoracoscopic posterior tracheopexy during primary esophageal atresia repair: a new approach to prevent tracheomalacia complications. J Pediatr Surg 2018;53(7):1420-1423.

72. Fung SW, Lapidus-Krol E, Chiang M, Fallon EM, Haliburton B, Propst EJ, Chiu PP. Vocal cord dysfunction following esophageal atresia and tracheoesophageal fistula (EA/TEF) repair. J Pediatr Surg 2019 .

73. Bednarczyk D, Sasiadek MM, Smigiel R. Chromosome Aberrations and Gene Mutations in Patients With Esophageal Atresia. J Pediatr Gastroenterol Nutr 2013;57(6):688-693.

74. Conforti A, Valfrè L, Scuglia M, Trozzi M, Meucci D, Sgrò S, Bottero S, Bagolan P. Laryngotracheal Abnormalities in Esophageal Atresia Patients: A Hidden Entity. Front Pediatr 2018;6:401.

75. Fayoux P, Morisse M, Sfeir R, Michaud L, Daniel S. Laryngotracheal anomalies associated with esophageal atresia: importance of early diagnosis. Eur Arch Oto-Rhino-Laryngology 2018;275(2):477-481.

76. Hseu A, Recko T, Jennings R, Nuss R. Upper Airway Anomalies in Congenital Tracheoesophageal Fistula and Esophageal Atresia Patients. Ann Otol Rhinol Laryngol 2015;124(10):808-813. 
77. van der Zee DC, van Herwaarden MYA, Hulsker CCC, Witvliet MJ, Tytgat SHA. Esophageal Atresia and Upper Airway Pathology. Clin Perinatol 2017;44(4):753-762.

78. Berthet S, Tenisch E, Miron MC, Alami N, Timmons J, Aspirot A, Faure C. Vascular anomalies associated with esophageal atresia and tracheoesophageal fistula. J Pediatr 2015;166(5):1140-1144.e2.

79. Choudhury roy s, Ashcraft keith W, Patrick murphy J, Snyder C, DL S. Survival of Patients With Esophageal Atresia: Influence of Birth Weight, Cardiac Anomaly, and Late Respiratory Complications. J Pediatr Surg 1999;34(1):70-74.

80. David TJ, O'Callaghan SE. Cardiovascular malformations and oesophageal atresia. Br Heart J 1974;36(6):559-565.

81. Lal DR, Gadepalli SK, Downard CD, Minneci PC, Knezevich M, Chelius TH, Rapp CT, Billmire D, Bruch S, Carland Burns R, et al. Infants with esophageal atresia and right aortic arch: Characteristics and outcomes from the Midwest Pediatric Surgery Consortium. J Pediatr Surg 2019;54(4):688-692.

82. Mowery N, Billmire DF, Schamberger M, Szotek P, West KW, Rescorla FJ, Scherer LR, Engum S, Rouse T, Grosfeld JL. Incidence of persistent left superior vena cava in esophageal atresia. J Pediatr Surg $2006 ; 41(3): 484-486$.

83. Wood JA, Carachi R. The Right-sided Aortic Arch in Children with Oesophageal Atresia and Tracheooesophageal Fistula. Eur J Pediatr Surg 2012;22(01):003-007.

84. Lejeune S, Le Mee A, Petyt L, Hutt A, Sfeir R, Michaud L, Fayoux P, Deschildre A, Gottrand F, Thumerelle C. Bronchopulmonary and vascular anomalies are frequent in children with oesophageal atresia. Acta Paediatr Int J Paediatr 2019;(November 2019):1221-1228.

85. Ashcraft KW, Sharp RJ, Snyder CL, Sigalet DL, Patrick J. Survival in EA-TEF: Influence of weight, CHD and late respiratory complications. 1999;34(1):70-74.

86. Su SC, Masters IB, Buntain H, Frawley K, Sarikwal A, Watson D, Ware F, Wuth J, Chang AB. A comparison of virtual bronchoscopy versus flexible bronchoscopy in the diagnosis of tracheobronchomalacia in children. Pediatr Pulmonol 2017;52(4):480-486.

87. Snijders D, Barbato A. An Update on Diagnosis of Tracheomalacia in Children. Eur J Pediatr Surg $2015 ; 25(04): 333-335$.

88. Hysinger EB, Hart CK, Burg G, De Alarcon A, Benscoter D. Differences in Flexible and Rigid Bronchoscopy for Assessment of Tracheomalacia. Laryngoscope 2020:1-4.

89. Ullmann N, Secinaro A, Menchini L, Caggiano S, Verrillo E, Santangelo TP, Cutrera R, Tomà P. Dynamic expiratory CT: An effective non-invasive diagnostic exam for fragile children with suspected tracheobronchomalacia. Pediatr Pulmonol 2018;53(1):73-80.

90. Ngerncham M, Lee EY, Zurakowski D, Tracy DA, Jennings R. Tracheobronchomalacia in pediatric patients with esophageal atresia: Comparison of diagnostic laryngoscopy/bronchoscopy and dynamic airway multidetector computed tomography. J Pediatr Surg 2015;50(3):402-407.

91. Boogaard R, Huijsmans SH, Pijnenburg MWH, Tiddens HAWM, de Jongste JC, Merkus PJFM. Tracheomalacia and Bronchomalacia in Children. Chest 2005;128(5):3391-3397.

92. Buitrago DH, Wilson JL, Parikh M, Majid A, Gangadharan SP. Current concepts in severe adult tracheobronchomalacia: Evaluation and treatment. J Thorac Dis 2017;9(1):E57-E66.

93. Acquisition D, Source P, Issues S, Protocol M, Analysis D, Parameters QC, Results R, Data R, Work F. ATS/ERS Statement: Raised volume forced expirations in infants - Guidelines for current practice. Am J Respir Crit Care Med 2005;172(11):1463-1471. 
94. Lodrup Carlsen KC, Magnus P, Carlsen KH. Lung function by tidal breathing in awake healthy newborn infants. Eur Respir J 1994;7(9):1660-1668.

95. Aworanti O, Awadalla S. Management of recurrent tracheoesophageal fistulas: A systematic review. Eur J Pediatr Surg 2014;24(5):365-375.

96. Bjornson C, Brindle M, Michelle Bailey JA, Mitchell I, Soles M. Delayed diagnosis of high proximal tracheoesophageal fistula in esophageal atresia and a novel approach to the treatment of tracheomalacia by submanubrial tracheopexy. Springerplus 2014;3(1):1-4.

97. Bruch SW, Hirschl RB, Coran AG. The diagnosis and management of recurrent tracheoesophageal fistulas. J Pediatr Surg 2010.

98. Coran AG. Diagnosis and surgical management of recurrent tracheoesophageal fistulas. Dis Esophagus 2013;26(4):380-381.

99. Guo W, Li Y, Jiao A, Peng Y, Hou D, Chen Y. Tracheoesophageal fistula after primary repair of type $\mathrm{C}$ esophageal atresia in the neonatal period: recurrent or missed second congenital fistula. J Pediatr Surg 2010;45(12):2351-2355.

100. Koivusalo AI, Pakarinen MP, Lindahl HG, Rintala RJ. Revisional surgery for recurrent tracheoesophageal fistula and anastomotic complications after repair of esophageal atresia in 258 infants. J Pediatr Surg 2015;50(2):250-254.

101. Platnaris A, Lianou D, Kaditis AG. Recurrent Tracheoesophageal Fistula in Children With Repaired Esophageal Atresia and the Usefulness of Flexible Bronchoscopy. Arch Bronconeumol 2015;51(1):49-50.

102. Smithers CJ, Hamilton TE, Manfredi MA, Rhein L, Ngo P, Gallagher D, Foker JE, Jennings RW. Categorization and repair of recurrent and acquired tracheoesophageal fistulae occurring after esophageal atresia repair. J Pediatr Surg 2017;52(3):424-430.

103. Meier JD, Sulman CG, Almond PS, Holinger LD. Endoscopic management of recurrent congenital tracheoesophageal fistula: A review of techniques and results. Int J Pediatr Otorhinolaryngol 2007;71(5):691697 .

104. Karnak I, Şenocak ME, Hiçsönmez A, Büyükpamukçu N. The diagnosis and treatment of H-type tracheoesophageal fistula. J Pediatr Surg 1997.

105. Wang J, Zhang M, Pan W, Wu W, Yan W, Cai W. Management of recurrent tracheoesophageal fistula after esophageal atresia and follow-up. Dis Esophagus 2017;30(9):1-8.

106. Ruiz AG, Bhatt JM, DeBoer EM, Friedlander J, Janosy N, Peterson MB, Wine T, Deterding R, Prager JD. Demonstrating the benefits of a multidisciplinary aerodigestive program. Laryngoscope 2020;130(2):521525 .

107. Deboer EM, Prager JD, Ruiz AG, Jensen EL, Deterding RR, Friedlander JA, Soden J. Multidisciplinary care of children with repaired esophageal atresia and tracheoesophageal fistula. Pediatr Pulmonol 2016;51(6):576-581.

108. Malmström K, Lohi J, Lindahl H, Pelkonen A, Kajosaari M, Sarna S, Malmberg LP, Mäkelä MJ. Longitudinal Follow-up of Bronchial Inflammation, Respiratory Symptoms, and Pulmonary Function in Adolescents after Repair of Esophageal Atresia with Tracheoesophageal Fistula. J Pediatr 2008;153(3):396401.

109. Jabbardarjani H, Kiani A, Arab A, Masjedi M. A Case of 50 Pneumonias in 13 Years. J Bronchology Interv Pulmonol 2009;16(2):112-114.

110. Pasteur MC, Bilton D, Hill AT. British thoracic society guideline for non-CF bronchiectasis. Thorax 2010;65(SUPPL. 1). 
111. Wu J, Chang AB, Wurzel DF. Contemporary management of bronchiectasis in children. Expert Rev Respir Med 2019;13(10):969-979.

112. Higano NS, Bates AJ, Tkach JA, Fleck RJ, Lim FY, Woods JC, Kingma PS. Pre- and post-operative visualization of neonatal esophageal atresia/tracheoesophageal fistula via magnetic resonance imaging. J Pediatr Surg Case Reports 2018;29:5-8.

113. Schäfer J, Griese M, Chandrasekaran R, Chotirmall SH, Hartl D. Pathogenesis, imaging and clinical characteristics of CF and non-CF bronchiectasis. BMC Pulm Med 2018;18(1):1-11.

114. Mahoney L, Rosen R. Feeding Difficulties in Children with Esophageal Atresia. Paediatr Respir Rev 2016;19:21-27.

115. Londahl M, Irace AL, Kawai K, Dombrowski ND, Jennings R, Rahbar R. Prevalence of laryngeal cleft in pediatric patients with esophageal atresia. JAMA Otolaryngol - Head Neck Surg 2018;144(2):164-168.

116. Watters KF, Ferrari L, Rahbar R. Laryngeal cleft. Adv Otorhinolaryngol 2012;73:95-100.

117. Williams JL, Lee EY, Casey AM, Haver KE, Buonomo C, Zurakowski D, Rahbar R. Chest radiographic and CT evaluation of lung abnormalities in pediatric patients with laryngeal cleft. Pediatr Pulmonol 2011;46(11):1128-1133.

118. Yalcin S, Demir N, Serel S, Soyer T, Tanyel FC. The evaluation of deglutition with videofluoroscopy after repair of esophageal atresia and/or tracheoesophageal fistula. J Pediatr Surg 2015;50(11):1823-1827.

119. Colombo J. Guest Editorial Guest Editorial. 2016;6(4):79-82.

120. Bauer L, Lyrene R. Chronic aspiration in children: Evaluation of the Lipid-Laden Macrophage Index. Pediatr Pulmonol 1999;28:94-100.

121. Kazachkov MY, Muhlebach MS, Livasy CA, Noah TL. Lipid-laden macrophage index and inflammation in bronchoalveolar lavage fluids in children. Eur Respir J 2001;18(5):790-795.

122. Reilly B, Katz E, Misono A, Khatwa U, Didas A, Huang L, Haver K, Rahbar R. Chronic aspiration in children: Evaluation of the lipid-laden macrophage index. Laryngoscope 22011;121:1055-1059.

123. Abdallah AF, El-Desoky T, Fathi K, Elkashef WF, Zaki A. Clinical utility of bronchoalveolar lavage pepsin in diagnosis of gastroesophageal reflux among wheezy infants. Can Respir J 2016;2016.

124. Alexiou S, Rakoczy KJ, Maupin KD. Bronchoalveolar Lavage Pepsin Activity And Lipid Laden Macrophages In Infants With Laryngomalacia And Gastroesophageal Reflux. 2010. p. A6235-A6235.

125. Lazow SP, Ben-Ishay O, Aribindi VK, Staffa SJ, Pluchinotta FR, Schecter SC, Cauley RP, Tworetzky W, Lee H, Moon-Grady AJ, et al. Predictors of index admission mortality and morbidity in contemporary esophageal atresia patients. J Pediatr Surg 2020;S0022-3468(xxxx).

126. Javia L, Harris MA, Fuller S. Rings, slings, and other tracheal disorders in the neonate. Semin Fetal Neonatal Med 2016;21(4):277-284.

127. Kay-Rivest E, Baird R, Laberge JM, Puligandla PS. Evaluation of aortopexy in the management of severe tracheomalacia after esophageal atresia repair. Dis Esophagus 2015;28(3):234-239.

128. Hunt RW, Perkins EJ, King S. Peri-operative management of neonates with oesophageal atresia and tracheo-oesophageal fistula. Paediatr Respir Rev 2016;19(2016):3-9.

129. Edelman B, Selvaraj BJ, Joshi M, Patil U, Yarmush J. Anesthesia Practice: Review of Perioperative Management of H-Type Tracheoesophageal Fistula. Anesthesiol Res Pract 2019;2019.

130. Lee S. Basic Knowledge of Tracheoesophageal Fistula and Esophageal Atresia. Adv Neonatal Care 2018;18(1):14-21. 
131. Vézina K, Laberge S, Nguyen TTD. Home high-flow nasal cannula as a treatment for severe tracheomalacia: A pediatric case report. Pediatr Pulmonol 2017;52(8):E43-E45.

132. Milési C, Boubal M, Jacquot A, Baleine J, Durand S, Odena MP, Cambonie G. High-flow nasal cannula: Recommendations for daily practice in pediatrics. Ann Intensive Care 2014;4(1):1-7.

133. Masui D, Fukahori S, Hashizume N, Ishii S, Yagi M. High-flow nasal cannula therapy for severe tracheomalacia associated with esophageal atresia. Pediatr Int 2019;61(10):1060-1061.

134. Ferrand A, Roy SK, Faure C, Moussa A, Aspirot A. Postoperative noninvasive ventilation and complications in esophageal atresia-tracheoesophageal fistula. J Pediatr Surg 2019;54(5):945-948.

135. Shah PS, Gera P, Gollow IJ, Rao SC. Does continuous positive airway pressure for extubation in congenital tracheoesophageal fistula increase the risk of anastomotic leak? A retrospective cohort study. J Paediatr Child Health 2016;52(7):710-714.

136. Rijnberg FM, Butler CR, Bieli C, Kumar S, Nouraei R, Asto J, McKavanagh E, De Coppi P, Muthialu N, Elliott MJ, et al. Aortopexy for the treatment of tracheobronchomalacia in 100 children: A 10-year single-centre experience. Eur J Cardio-thoracic Surg 2018;54(3):585-592.

137. Arnaud AP, Rex D, Elliott MJ, Curry J, Kiely E, Pierro A, Cross K, Coppi P De. Early Experience of Thoracoscopic Aortopexy for Severe Tracheomalacia in Infants After Esophageal Atresia and Tracheoesophageal Fistula Repair. J Laparoendosc Adv Surg Tech 2014;24(7):508-512.

138. Jennings RW, Hamilton TE, Smithers CJ, Ngerncham M, Feins N, Foker JE. Surgical approaches to aortopexy for severe tracheomalacia. J Pediatr Surg 2014;49(1):66-71.

139. Shieh HF, Smithers CJ, Hamilton TE, Zurakowski D, Visner GA, Manfredi MA, Baird CW, Jennings RW. Posterior Tracheopexy for Severe Tracheomalacia Associated with Esophageal Atresia (EA): Primary Treatment at the Time of Initial EA Repair versus Secondary Treatment. Front Surg 2018;4.

140. Shieh HF, Smithers CJ, Hamilton TE, Zurakowski D, Visner GA, Manfredi MA, Jennings RW, Baird CW. Descending Aortopexy and Posterior Tracheopexy for Severe Tracheomalacia and Left Mainstem Bronchomalacia. Semin Thorac Cardiovasc Surg 2019;31(3):479-485.

141. Watters KF. Tracheostomy in infants and children. Respir Care 2017;62(6):799-825.

142. Tweedie DJ, Cooke J, Stephenson KA, Gupta SL, Pepper CM, Elloy MD, Cochrane LA, Wyatt ME. Paediatric tracheostomy tubes: Recent developments and our current practice. J Laryngol Otol 2018;132(11):961-968.

143. Wallis C, Alexopoulou E, Antón-Pacheco JL, Bhatt JM, Bush A, Chang AB, Charatsi A-M, Coleman C, Depiazzi J, Douros K, et al. ERS statement on tracheomalacia and bronchomalacia in children.

144. Bass R, Santiago M, Smith L, Quinlan C, Panitch H, Giordano T, Piccione J. Bethanechol in Tracheomalacia: Two Case Series and a Review of the Literature. Pediatr Allergy, Immunol Pulmonol 2018;31(3):180183.

145. Patria MF, Esposito S. Recurrent Lower Respiratory Tract Infections in Children: A Practical Approach to Diagnosis. Paediatr Respir Rev 2013;14(1):53-60.

146. Merkus PJFM. That antibiotic prophylaxis should be used in children with repaired oesophageal atresia and or trachea-oesophageal fistula - The case in favourNo Title. Paediatr Respir Rev 2016;18:60-61.

147. Warris A. Prophylactic antibiotics should be used in children with repaired oesophageal atresia and tracheo-oesophageal fistula: The case against. Paediatr Respir Rev 2016;18(2016):62-63.

148. Fitzgerald DA. Pro -con debate: "That antibiotic prophylaxis should be used in children with repaired oesophageal atresia and tracheo-oesophageal fistula." Paediatr Respir Rev 2016;18(2016):58-59. 
149. Cramer CL, Patterson A, Alchakaki A, Soubani AO. Immunomodulatory indications of azithromycin in respiratory disease: a concise review for the clinician. Postgrad Med 2017;129(5):493-499.

150. da Silva Filho LVRF, Pinto LA, Stein RT. Use of macrolides in lung diseases: recent literature controversies. J Pediatr (Rio J) 2015;91(6):S52-S60.

151. Huttner A, Bielicki J, Clements MN, Frimodt-Møller N, Muller AE, Paccaud JP, Mouton JW. Oral amoxicillin and amoxicillin-clavulanic acid: properties, indications and usage. Clin Microbiol Infect 2020;(xxxx).

152. Deboer EM, Prager JD, Ruiz AG, Jensen EL, Deterding RR, Friedlander JA, Soden J. Multidisciplinary care of children with repaired esophageal atresia and tracheoesophageal fistula. Pediatr Pulmonol 2016;51(6):576-581.

153. Bjornson CL, Mitchell I. Congenital tracheoesophageal fistula and coordination of care: Expectations and realities. Paediatr Child Health 2006;11(7):395-399.

154. Carden KA, Boiselle PM, Waltz DA, Ernst A. Tracheomalacia and tracheobronchomalacia in children and adults: An in-depth review. Chest 2005;127(3):984-1005.

155. Sadreameli SC, McGrath-Morrow SA. Respiratory Care of Infants and Children with Congenital Tracheo-Oesophageal Fistula and Oesophageal Atresia. Paediatr Respir Rev 2016;17:16-23.

156. Thakkar HS, Hewitt R, Cross K, Hannon E, De Bie F, Blackburn S, Eaton S, McLaren CA, Roebuck DJ, Elliott MJ, et al. The multi-disciplinary management of complex congenital and acquired tracheo-oesophageal fistulae. Pediatr Surg Int 2019;35(1):97-105.

157. Dellenmark-Blom M, Chaplin JE, Gatzinsky V, Jönsson L, Abrahamson K. Health-related quality of life among children, young people and adults with esophageal atresia: a review of the literature and recommendations for future research. Qual Life Res 2015;24(10):2433-2445.

158. Dingemann C, Eaton S, Aksnes G, Bagolan P, Cross KM, De Coppi P, Fruithof J, Gamba P, Husby S, Koivusalo A, et al. ERNICA Consensus Conference on the Management of Patients with Esophageal Atresia and Tracheoesophageal Fistula: Follow-up and Framework. Eur J Pediatr Surg 2019.

159. Rozensztrauch A, Śmigiel R, Błoch M, Patkowski D. The Impact of Congenital Esophageal Atresia on the Family Functioning. J Pediatr Nurs 2020;50:e85-e90.

160. Witt S, Bloemeke J, Bullinger M, Dingemann J, Dellenmark-Blom M, Quitmann J. Agreement between mothers', fathers', and children's' ratings on health-related quality of life in children born with esophageal atresia - a German cross-sectional study. BMC Pediatr 2019;19(1).

161. Mudd PA, Silva AL, Callicott SS, Bauman NM. Cost Analysis of a Multidisciplinary Aerodigestive Clinic: Are Such Clinics Financially Feasible? Ann Otol Rhinol Laryngol 2017;126(5):401-406.

162. Collaco JM, Aherrera AD, Au Yeung KJ, Lefton-Greif MA, Hoch J, Skinner ML. Interdisciplinary pediatric aerodigestive care and reduction in health care costs and burden. JAMA Otolaryngol - Head Neck Surg 2015;141(2):101-105.

163. Bustamante-Marin XM, Ostrowski LE. Cilia and mucociliary clearance. Cold Spring Harb Perspect Biol 2017;9(4):1-17.

164. Volsko TA. Airway clearance therapy: Finding the evidence. Respir Care 2013;58(10):1669-1678.

165. Van Der Schans CP, Postma DS, Koëter GH, Rubin BK. Physiotherapy and bronchial mucus transport. Eur Respir J 1999;13(6):1477-1486.

166. Olsén MF, Lannefors L, Westerdahl E. Positive expiratory pressure - Common clinical applications and physiological effects. Respir Med 2015;109(3):297-307. 
167. Rosen R, Vandenplas Y, Singendonk M, Cabana M, Dilorenzo C, Gottrand F, Gupta S, Langendam M, Staiano A, Thapar N, et al. Pediatric Gastroesophageal Reflux Clinical Practice Guidelines: Joint Recommendations of the North American Society for Pediatric Gastroenterology, Hepatology, and Nutrition and the European Society for Pediatric Gastroenterology, Hepatology, and Nutritio. J Pediatr Gastroenterol Nutr 2018;66(3):516-554.

168. Grunder FR, Petit LM, Ezri J, Jantchou P, Aspirot A, Laberge S, Faure C. Should Proton Pump Inhibitors be Systematically Prescribed in Patients with Esophageal Atresia after Surgical Repair? J Pediatr Gastroenterol Nutr 2019;69(1):45-51.

169. Sabater JR, Lee TA, Abraham WM. Comparative effects of salmeterol, albuterol, and ipratropium on normal and impaired mucociliary function in sheep. Chest 2005;128(5):3743-3749.

170. Panitch HB, Keklikian EN, Motley RA, Wolfson MR, Schidlow D V. Effect of altering smooth muscle tone on maximal expiratory flows in patients with tracheomalacia. Pediatr Pulmonol 1990;9(3):170-176.

171. Gallagher T, Maturo S, Fracchia S, Hartnick C. An analysis of children with tracheomalacia treated with ipratropium bromide (Atrovent). Laryngoscope 2011;121(SUPPL. 4):S211.

172. Shah V, Husta B, Mehta A, Ashok S, Ishikawa O, Stoffels G, Hartzband J, Lazzaro R, Patton B, Lakticova V, et al. Association Between Inhaled Corticosteroids and Tracheobronchomalacia. Chest 2020;(April):1-9.

173. O'Donnell AE, Barker AF, Ilowite JS, Fick RB. Treatment of idiopathic bronchiectasis with aerosolized recombinant human DNase I. Chest 1998;113(5):1329-1334.

174. Custer R, Scarcella J, Stewart B. Journal of Career and Technical. J Career Tech Educ 1999;15(2):1-10.

175. Dijkers M. Introducing GRADE: a systematic approach to rating evidence in systematic reviews and to guideline development. e-newsletter Cent Knowl Transl Disabil Rehabil Res 2013;1(5):1-9.

176. Guyatt GH, Oxman AD, Vist G, Kunz R, Brozek J, Alonso-Coello P, Montori V, Akl EA, Djulbegovic B, Falck-Ytter Y, et al. GRADE guidelines: 4. Rating the quality of evidence - Study limitations (risk of bias). J Clin Epidemiol 2011.

\section{LEGENDS - FIGURES}

Figure 1. Schematic presentation of the methodology for the development of the recommendations on the diagnosis \& management of the respiratory complications of EA-TEF.

Figure 2. Schematic diagram of the pathophysiology of the respiratory complications of TEF.

Figure 3A. MEFVCs in a child with EA-TEF and tracheomalacia.Red line (Baseline ). The flow-volume curve is concave consistent with significant lower airway obstruction. The partial collapse of the trachea affects the initial portion of the MEFVC causing greater decrease in the FEFmax and the $\mathrm{FEF}_{25}$ than on the $\mathrm{FEV}_{1}$. . The inspiratory flow-volume loop is normal.Green line (post-bronchodilator ): There is more extensive flattening of the MEFVC reflecting increased collapse of the trachea and major bronchii due to overrelaxation of the airway smooth muscle. The inspiratory flow-volume loop remains normal.

3B. Tidal flow-volume loop in an infant with significant tracheomalacia. The flattening of the expiratory tidal loop is due to the collapse of the trachea on expiration, while the inspiratory flow-volume loop is normal. The ratio of the maximal expiratory to the maximal inspiratory flow (ME/MI) that is normally approximately 1 , is only 0.3 . The tidal inspiratory and expiratory volumes are not affected.

\section{LEGENTS - IMAGES}

Image. Tracheoesophageal fistula \& Tracheobronchomalacia: (A)TEF post repair. Note the ridge on the posterior tracheal wall above the carina as well a visible pouch (the pouch is often closed); (B)At rest, the mid-trachea maintains its characteristic "horseshoe" shape; (C): Severe obstruction of the trachea 
lumen and change in its shape due to the intrusion of the posterior membranous wall into the lumen during cough; (D): Almost complete occlusion of the Right Main Stem Bronchus during cough

Step 1. REVIEW OF EVIDENCE \& DETERMINATION OF KEY CLINICAL VARIABLES

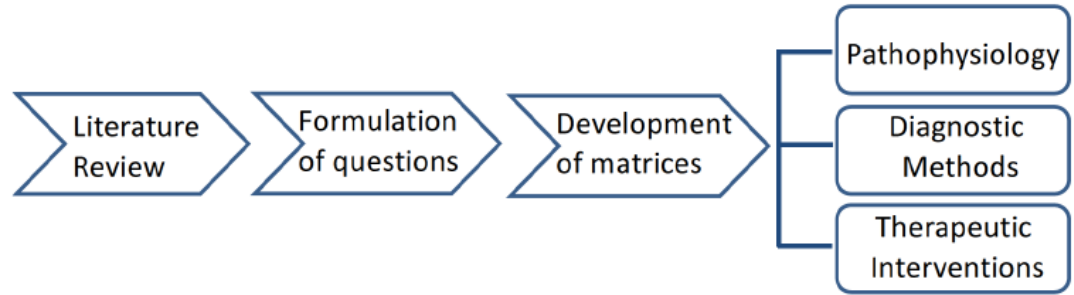

Step 2. RATING FOR APPROPRIATNESS (All 3 categories)

Inappropriate
$1-2-3$ $\begin{gathered}\text { Uncertain } \\ 4-5-6\end{gathered} \quad \begin{gathered}\text { Appropriate } \\ 7-8-9\end{gathered}$

Step 3. RATING FOR NECESSITY (Diagnostic Methods \& Therapeutic Interventions)

\begin{tabular}{|c|c|}
\hline Unnecessary \\
$1-2-3$
\end{tabular} $\begin{gathered}\text { Uncertain } \\
4-5-6\end{gathered} \quad \begin{gathered}\text { Nessary } \\
7-8-9\end{gathered}$

Step 4. FORMULATION OF THE RECOMMENDATIONS

\section{POSITION PAPER}

\begin{tabular}{|c|c|c|}
\hline $\begin{array}{l}\text { PATHOPHYSIOLOGY OF } \\
\text { TRACHEOMALACIA }\end{array}$ & CLINICAL FEATURES & COMPLICATING FACTORS \\
\hline Cartilage/Cilia Deficiency & NEONATES-INFANTS & Vocal Cord Paralysis \\
\hline$v$ & Respiratory Distress & Extrinsic tracheal compression \\
\hline Airway Collapse & Hypoxemic spells & Esophageal stricture \\
\hline 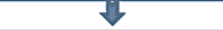 & Recurrent harsh wheeze & Food bolus \\
\hline Retention of Secretions & Honking/Brassy Cough & \\
\hline v & & Laryngeal Cleft \\
\hline Bacterial Colonization & & Swallowing impairment \\
\hline v & & Recurrent TEF \\
\hline Chronic Bronchitis & $\begin{array}{l}\text { CHILDREN-ADOLESCENTS } \\
\text { Recurrent Wheeze }\end{array}$ & Gastroesophageal Reflux \\
\hline$v$ & Honking/Brassy Cough & Regurgitation \\
\hline Recurrent Pneumonia & Hoarseness/Stridor & \\
\hline$y$ & Exercise intolerance & Cardiac/Vascular Anomalies \\
\hline Bronchiectasis & Impaired Lung Function & Allergic Sensitization \\
\hline
\end{tabular}



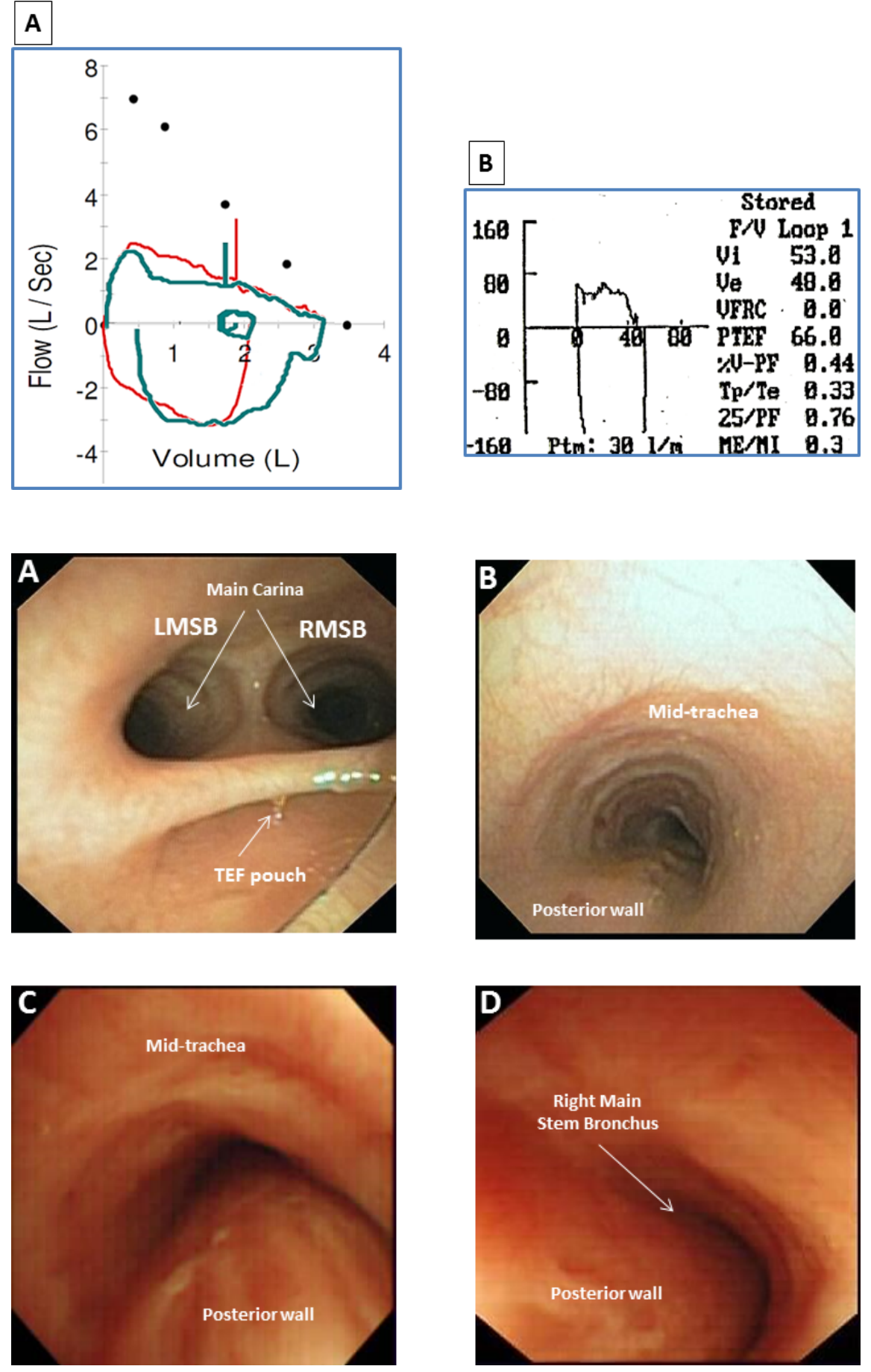

\section{Hosted file}

Table 1A. Respiratory Evaluation - Color.docx available at https://authorea.com/users/330300/ articles/457132-care-recommendations-for-the-respiratory-complications-of-esophagealatresia-tracheoesophageal-fistula-the-international-network-of-esophageal-atresiarespiratory-complications-working-group 


\section{Hosted file}

Table 1B. Respiratory Evaluation - Color.docx available at https://authorea.com/users/330300/ articles/457132-care-recommendations-for-the-respiratory-complications-of-esophagealatresia-tracheoesophageal-fistula-the-international-network-of-esophageal-atresiarespiratory-complications-working-group

\section{Hosted file}

Table 2 - Color.docx available at https://authorea.com/users/330300/articles/457132care-recommendations-for-the-respiratory-complications-of-esophageal-atresiatracheoesophageal-fistula-the-international-network-of-esophageal-atresia-respiratorycomplications-working-group

\section{Hosted file}

Table 1A. Respiratory Evaluation - Grey.docx available at https://authorea.com/users/330300/ articles/457132-care-recommendations-for-the-respiratory-complications-of-esophagealatresia-tracheoesophageal-fistula-the-international-network-of-esophageal-atresiarespiratory-complications-working-group

\section{Hosted file}

Table 1B. Respiratory Evaluation - Grey.docx available at https://authorea.com/users/330300/ articles/457132-care-recommendations-for-the-respiratory-complications-of-esophagealatresia-tracheoesophageal-fistula-the-international-network-of-esophageal-atresiarespiratory-complications-working-group

\section{Hosted file}

Table 2 - Grey.docx available at https://authorea.com/users/330300/articles/457132care-recommendations-for-the-respiratory-complications-of-esophageal-atresiatracheoesophageal-fistula-the-international-network-of-esophageal-atresia-respiratorycomplications-working-group

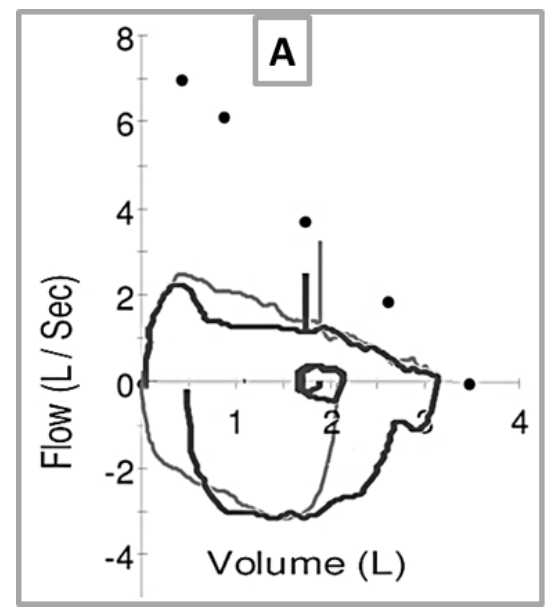

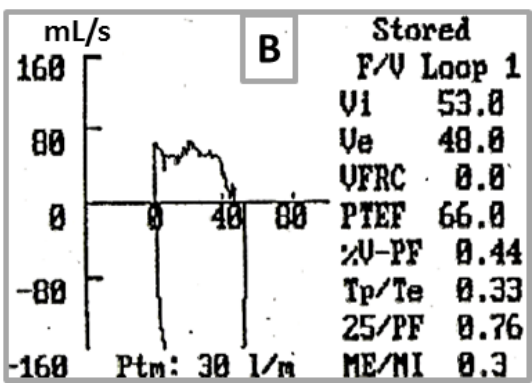



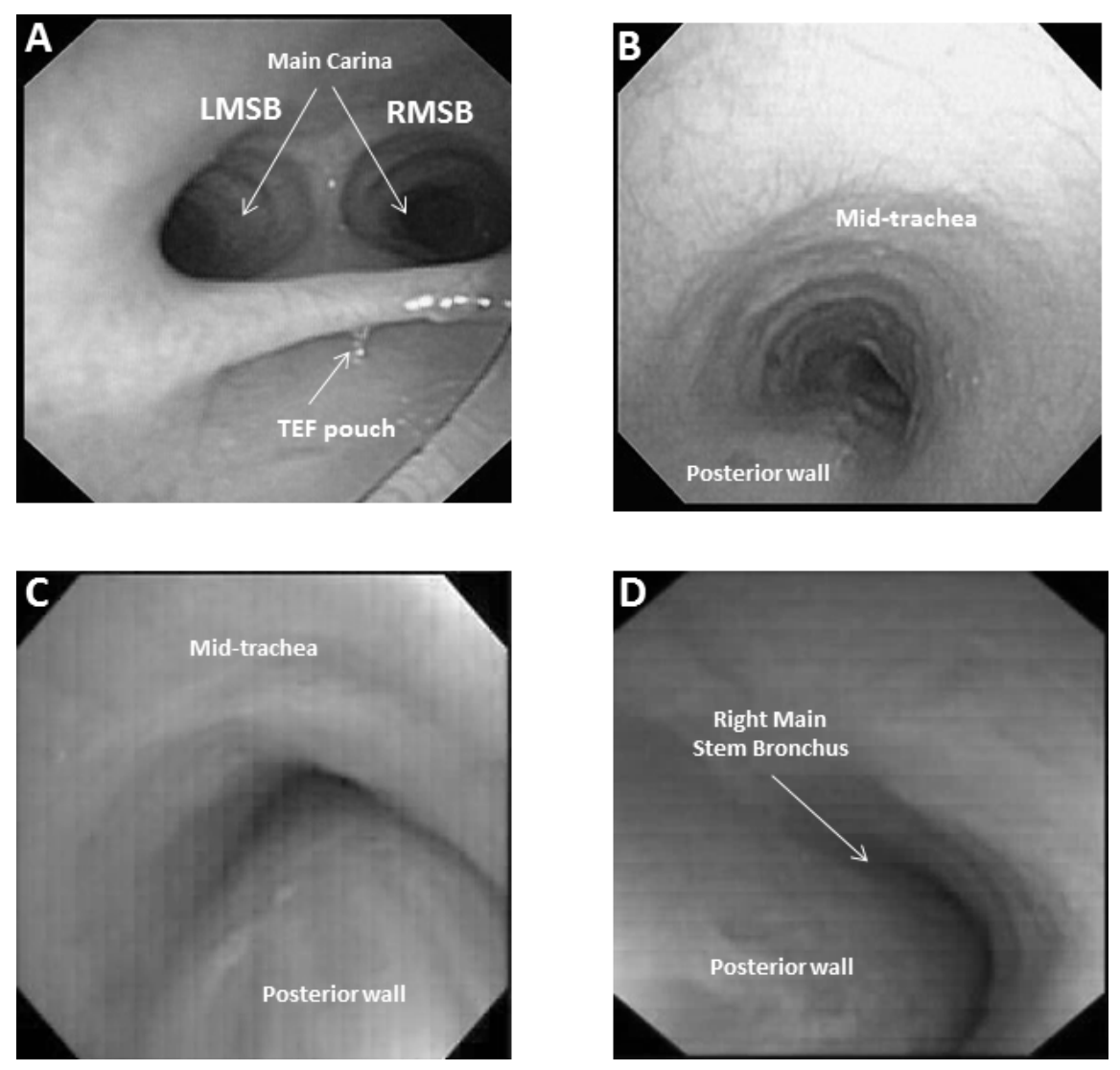